\title{
Comparison of Mycobacterium Avium Subsp. Paratuberculosis (MAP) Infection in Cattle, Sheep and Goats Following the Detection of Clinical Cases: Fact and Fiction
}

Mahdi Pourmahdi Borujeni ( $\square$ pourmahdim@scu.ac.ir)

Shahid Chamran University of Ahvaz

Mohammad Rahim Haji Hajikolaei

Shahid Chamran University of Ahvaz

Masoud Ghorbanpoor

Shahid Chamran University of Ahvaz

Hamzeh Elhaei Sahar

Shahid Chamran University of Ahvaz

Saeed Bagheri

Shahid Chamran University of Ahvaz

Sanaz Roveyshedzadeh

Shahid Chamran University of Ahvaz

Research article

Keywords: Epidemiology, Johne's disease, Mycobacterium avium subsp. Paratuberculosis, Serology

Posted Date: July 17th, 2020

DOI: https://doi.org/10.21203/rs.3.rs-41378/v1

License: (c) (i) This work is licensed under a Creative Commons Attribution 4.0 International License.

Read Full License 


\section{Abstract}

Background: Paratuberculosis or Johne's disease, caused by Mycobacterium avium subsp. paratuberculosis (MAP), is chronic infectious granulomatous enteritis of ruminants, which has a worldwide occurrence. The most common symptoms of this disease in cattle are loss of milk production, weight loss, and diarrhea and in sheep and goats are emaciation, anorexia and sever disability. The aim of this study was to compare the seroprevalence of MAP in cattle, sheep and goats following the detection of clinical cases in Southwest of Iran. Blood samples were randomly collected from 530 cattle, 568 sheep and 368 goats in Southwest of Iran. Sera were tested by a commercial ELISA kit for detection of antibodies to MAP.

Results: Overall apparent and true seroprevalence rate of MAP was $6 \%$ (95\% Cl: $4.9-7.3$ percent) and 11.36\% (95\% Cl: 9.87 - 13.07 percent), respectively. Apparent and true seroprevalence of MAP were 4.34\% (95\% Cl: 2.88 - 6.46 percent) and 7.59\% (95\% Cl: $5.61-10.19$ percent), respectively in cattle, 6.87\% (95\% Cl: 5.05 - 9.27 percent) and 13.34\% (95\% Cl: 10.78 - 16.4 percent), respectively in sheep, and $7.07 \%$ ( 95\% Cl: 4.82 - 10.18 percent) and 13.68\% (95\% Cl: $10.52-17.58$ percent), respectively in goats. As a result, there was no significant relationship between species and MAP infection. Moreover, multivariate logistic regression showed that the infection rate is not associated with age, gender, and geographical location in cattle, sheep and goats $(P>0.05)$.

Conclusions: This study confirms that the seroprevalence of MAP following the detection of clinical cases is considerable in the cattle, sheep and goats in Southwest of Iran, although in cattle it is less than goats and sheep. Therefore, preventive and control measures should be considered by animal health authorities and meat and dairy processing units.

\section{Background}

The Johne's disease (JD), which is a chronic infectious granulomatous enteritis of ruminants, is caused by Mycobacterium avium subsp. paratuberculosis (MAP). This disease is unique to cattle; however, it could be also seen in sheep, goats, and wild ruminants [1-3]. Given the economic importance of the JD in the world, as one of the priorities of diseases, infections and infestations have been announced by the OIE in 2020 [4]. The symptoms of this disease, in cattle, at the final stage include loss of milk production, loss of weight, chronic and intermittent diarrhea, and anemia which finally results in death [5]. In sheep and goats the most common clinical sings are emaciation, anorexia and sever disability $[6,7]$. This disease is also important from the standpoint of public health because the cause of JD is related to the Crohn's disease in human $[8,9]$. In the same vein, positive and consistent associations between MAP and Crohn's disease have been reported by Waddell et al. (2015) in a systematic review and meta-analysis study [10]. In fact, the transfer of MAP occurs both horizontally and vertically. More specifically, in young animals, it is caused by drinking infected milk and colostrum and also eating food contaminated with feces. It can also be transmitted from an infected pregnant animal to its fetus. The calves under thirty days are more sensitive to this agent that remains silent in the body for almost six months to three years 
[11-15]. There are three groups of MAP strains which appeared to correlate with the host of origin and were designated "Sheep-type" (type S), "Cattle-type" (type C) and "Bison-type" (type B). However, the relationship between strain type and the host species was neither absolute nor always clear. For example, type $S$ strains are more frequent in New Zealand beef cattle than type $C$ strains where these species are frequently grazed together. Type $\mathrm{C}$ strains are isolated from a broad range of hosts and do not appear to have a host preference. The evidence for inter-species transmission is compelling, but the risk of natural transmission of type $S$ strains from sheep and goats to cattle is low and occurs only when susceptible animals are exposed to high doses $[16,17]$.

Due to the long incubation period of JD and the role of cattle, sheep and goats as incubatory carrier and distribution of the MAP with no sings, identifying the infection is very important. In the same line, the best strategy to prevent the infection is to identify and cull the infected animals. Therefore, diagnosis of paratuberculosis is possible through molecular, culture and serology methods which are less sensitive; thus, the infection rate is estimated less than true value and the iceberg phenomenon is seen in this disease $[15,18,19]$. Moreover, the definite diagnosis is possible through time consuming culture; but, the cheapest and fastest method is ELISA which is a suitable diagnostic tool for detecting antibodies against this organism on a large scale $[5,20]$. Due to the economic importance of paratuberculosis, many studies have been conducted on its epidemiology in the world. In Iran, also, the prevalence of this disease varies in cattle between 2-59\% [21-30] and in sheep and goats between $0.96-37 \%$ [31,32]. The JD has been diagnosed in cattle, buffaloes, sheep and goats, in the hospital of Faculty of Veterinary Medicine in Shahid Chamran University of Ahvaz, based on clinical signs, histopathology and molecular testing. Despite the importance of issue, no epidemiological study on seroprevalence and risk factors of MAP infection has been conducted in this area. Therefore, the present study is an attempt to identify both the infection rate of MAP in cattle, sheep and goats and the role of the risk factors including species, age, sex and geographical location. Apparently, identifying the prevalence rate in this chronic disease, the animal health authorities will be able to use the information to follow the prevention policies and provide the evaluation of control programs.

\section{Results}

\section{Seroprevalence of MAP}

The overall apparent and true seroprevalence rate of MAP was 6\% (95\% Cl: $4.9-7.3$ percent) and $11.36 \%$ (95\% Cl: 9.87 - 13.07 percent), respectively. Apparent and true seroprevalence rate of MAP respectively was $4.34 \%$ (95\% Cl: $2.88-6.46$ percent) and $7.59 \%$ (95\% Cl: $5.61-10.19$ percent) in cattle, $6.87 \%$ (95\% Cl: 5.05 - 9.27 percent) and 13.34\% (95\% Cl: 10.78 - 16.4 percent) in sheep, and 7.07\% (95\% Cl: 4.82 10.18 percent) and $13.68 \%$ (95\% Cl: $10.52-17.58$ percent) in goats.

\section{The role of the species}


There was no significant relationship between species and infection $\left(X^{2}=4.09, d f=2, P=0.13\right)$. In comparison with the cattle, the odds of infection in the sheep and goats were 1.63 (95\% Cl: 0.96-2.76, $\mathrm{P}=0.07)$ and 1.68 (95\% Cl: $0.94-2.99, \mathrm{P}=0.08)$, respectively; in this regard, $0.8 \%$ of fluctuation in infection was justified by species.

\section{The role of the age}

The Chi-square test showed that the infection is not associated with age orders in cattle $\left(\chi^{2}=0.38, d f=2\right.$, $P=0.83)$, sheep $\left(X^{2}=1.29, d f=2, P=0.52\right)$ and goats $\left(X^{2}=0.18, d f=2, P=0.92\right)$; however, it increases with aging in cattle and in goats and decreases in sheep. The odds of infection between the age, based on the year and disease in cattle and goats are 1.02 and 1.08, respectively, implying that the odds of infection increased $2 \%$ and $8 \%$ with rising one year of age. Moreover, $0.4 \%$ and $0.3 \%$ of fluctuation in infection was justified by age in cattle and goats, respectively. In sheep, the odds of infection between the age, based on the year and disease is 0.96 implying that the odds of infection decreased $4 \%$ with rising one year of age. Furthermore, $0.1 \%$ of fluctuation in infection was justified by age (tables 1,2 , and 3 ). The average age of infected cattle, sheep and goats was 4.2, 3.8 and 3.5 years, respectively, whose difference was not statistically significant $\left(X^{2}=2.9, d f=2, P=0.24\right)$. Besides, the difference between the average age of infected/non-infected cattle (4.2/ 4.1 years, $P=0.48)$, sheep (3.7/4 years, $P=0.3)$ and goats (3.5/3.2 years, $\mathrm{P}=0.37)$ was not statistically significant.

\section{The role of sex}

Although the prevalence of MAP infection in female cattle, sheep and goats was higher than males, there was no significant difference between these sex groups according to the chi-square test (in cattle: $\chi^{2}=$ $0.42, \mathrm{df}=1, \mathrm{P}=0.52$; in sheep: $\chi^{2}=0.95, \mathrm{df}=1, \mathrm{P}=0.33$; in goats: $\chi^{2}=0.002, \mathrm{df}=1, \mathrm{P}=0.96$ ). Obviously, the odds of infection in female cattle, sheep and goats were $1.94,3.45$ and 1.19 , respectively compared to those of males. Furthermore, $0.3 \%, 1 \%$ and $0.1 \%$ of fluctuation in infection was justified by gender in cattle, sheep and goats, respectively (tables 1,2 , and 3 ).

\section{The role of the geographical location}

The infection rates varied among different cities ranging from zero to 12.07 percent in cattle $\left(\chi^{2}=17.62\right.$, $\mathrm{df}=8, P=0.02)$. However, chi square test showed that the infection is not associated with geographical location in sheep $\left(X^{2}=5.59, d f=6, P=0.36\right)$ and goats $\left(X^{2}=7.37, d f=5, P=0.2\right)$. Moreover, $12.3 \%, 2.9 \%$ and $4.9 \%$ of fluctuation in infection were justified by geographical location respectively in cattle, sheep and goats (tables 1, 2, and 3). Cramer's V coefficient between infection rate in cattle, sheep and goats in, Ahvaz, Dezful, Hendijan and Susangerd was $0.19,0.07,0.11$ and 0.15 , respectively.

\section{Multivariate analysis}

Multivariate logistic regression in cattle, sheep and goats showed that $12.4 \%, 4 \%$ and $5.3 \%$ of fluctuation in infection were justified by age, sex and geographical location, respectively. However, in backward 
stepwise logistic regression, none of them had a significant effect on infection.

\section{Discussion}

The present epidemiological study was an attempt to evaluate and compare the seroprevalence of MAP with ELISA method in the cattle, sheep and goats following the detection of clinical cases. Moreover, the relationship between the infection with determinants such as species, age, gender and geographical location was investigated. In MAP infection, there is a relationship between active infection and shedding with high serum antibody titre [33-35]. Therefore, in this study, the results of ELISA indicated antibodies in cattle, sheep and goats that might have active infection and possibly shed MAP in their faeces and milk; however, animals with subclinical infection may be missed. Collins et al. (2005) showed that there is a direct relationship between the magnitude of ELISA results and the odds of a cow shedding MAP [33]. The results indicated that following the detection of clinical cases, the apparent and true seroprevalence of MAP respectively is $4.34 \%$ and $7.59 \%$ in cattle, $6.87 \%$ and $13.34 \%$ in sheep, and $7.07 \%$ and $13.68 \%$ in goats. Thus, in an endemic area, the rate of infection is similar in cattle, sheep and goats and so the species is not a risk factor for it. Also, Cramer's V coefficient showed that there is a very slight to slight relationship in seropositivity rates between these species in 4 cities, including Susangerd, Ahvaz, Dezful and Hendijan.

In addition, there are reports that indicate the prevalence of infection in herd and livestock in different contries; however, because different methods have been used for detection of MAP antibodies and the difference existing in host and environmental dereminants, it is difficult to compare them with each other $[7,36]$. For example, the frequency of MAP infection in slaughtered cattle in Ahvaz abbatoir was $3 \%$ and $2 \%$ by ELISA and Ziehl-Neelsen staining methods, respectively $[22,29,30]$ but in sheep and goats in the same slaughterhouse by Ziehl-Neelsen staining, was $1.4 \%$ and $0.96 \%$, respectively [31]. In other areas of Iran, the MAP infection rate in cattle was $3.6-25 \%$ by ELISA, PCR, culture and Ziehl-Neelsen staining methods which sera, milk, and feces were used [21, 23-28]. The prevalence of MAP infection in cattle from other countries has been reported to be 2.31 to $70.4 \%$ [37-46]. The MAP infection rate in goats from some area of Iran was $37 \%$ and $17.3 \%$ by PCR and culture methods, respectively [32] but it was $0.3-$ $45.1 \%$ in other countris [47-56]. The prevalence of infection in sheep has been reported as $2.4-21.1 \%$ $[48-50,53,57,58]$. A quick glance at the results of these studies shows that they are different. This may be due to the difference in the sample size, sampling method, methods of examination, herd size and managment, environmental and host determinants. In order to diagnose the infection to MAP, different methods such as fecal culture, Ziehl-Neelsen staining (different parts of the intestine, lymph node of ileocecal valve and other parts of intestine and fece), PCR, ELISA, CFT and AGID are used. Both the sensitivity and specificity of each of the above methods are different. That is why, the type of diagnostic test used in the study of could be referred to as one of the basic reasons of the difference existing in the frequency of infection to MAP. Moreover, scince the cattle in a herd infected by MAP are divided into four groups as those: 1- exposing clinical symptoms and excreting the bacteria; 2- being subclinically infected and excreting the bacteria; 3 - being infected by MAP but not excreting the bacteria to the extent that it could be traced; 4- not being infected [7], therefore, in addition to the difference in sensitivity and 
specificity, the above categorization can also affect the general outcome of using a specific method. For example, the sensitivity of fecal culture is different depending on the stage of disease. Different methods of serology seem to be different from the standpoint of sensitivity and specificity as follows: CFT $90 \%$ and $70 \%$, AGID $96 \%$ and $94 \%$ and ELISA $45 \%$ and $99 \%$, respectively (Constable et al., 2017). In general, studies show that the specificity of the ELISA kit is very high, but the sensitivity is low $[59,60]$. In diagnosing the infection in young and newly infected animals, because of the lack of enough antibody production, the ELISA has less sensitivity; thus, the diagnosis power of ELISA increases with advancement of the disease and the increase of antibody production [61]. Juste et al. (2005) examined the power of both ELISA and PCR in detecting MAP in cattle and sheep. They showed that out of 136 samples that had a positive result by ELISA or PCR, only 10 samples were positive by both methods, whereas 70 samples were positive only by ELISA and 56 samples by PCR. Therefore, agreement between the two tests was low. In fact, each method would detect different stages of MAP infection because their respective targets (bacteria and antibodies) might not have parallel dynamics. The young animals were more easily diagnosed by PCR than by ELISA, possibly because of the rapid recirculation of MAP-loaded phagocytic cells from the intestinal lymphoid tissue into other lymphoid tissues after the infection, reinfection, or reactivation [62]. This should be expected to be more frequent among young animals newly exposed to MAP than in adults known to be more resistant to infection. In contrast, because of the antibody response is slow to develop and highly dependent on the total number of mycobacteria, the most advanced cases should have detectable antibody responses [63-64]. In general, microscopic examination of feces and different parts of intestine mucus, using Ziehl-Neelsen staining method is not reliable enough to trace the MAP [7].

MAP is mostly transmitted to susceptible animals via ingestion of contaminated milk, water, and other feed products or uptake from the environment. With newborn calves being the most susceptible age group for MAP infection, contaminated colostrum and milk are considered a primary source of infection. MAP is introduced into milk and colostrum either via contaminated teats or direct shedding of the organism into the colostrum/ milk. In the same line, infected cattle and other species excrete MAP directly into the milk during at least the late disseminated stage of the infection. Therefore, there is resistance to disease increases with age and older animals appear susceptible to infection but relatively resistant to progression to disease. [65]. Experimental and field studies showed that infection becomes more difficult when calves are 4 months or older, and susceptibility to infection from 1 year of age on appears to be similar to that of adult animals [7]. The age of all the three examined species was more than 6 months old and had the same susceptibility to infection. For this reason, as results showed there was no significant relationship between age and infection in cattle, sheep and goats and most infections occurred in the early stages of life. Besides, in this study, the average age of infected cattle, sheep and goats was similarly about 4 years. In fact, the age of infection was the same in these species. Stau et al. (2012) and Morales-Pablos et al. (2020) also proved that there was no relationship between age and infection in sheep and goats [53,58]. However, Cetinkaya et al. (1996), Woodbine et al. (2009), Weber et al. (2010), Fecteau et al. (2010), Attili et al. (2011) and Karimi et al. (2012) showed that age was significantly related to infection $[6,26,66-69]$. This reported relationship may be due to bias types 
including, selection, information or measurement, confounders such as husbandry and management and selected statistical method.

In this study, the relative frequency of positive cases in females and males was the same. Also, Kimberling (1988), Anderson et al. (1992), Karimi et al. (2012), Stau et al. (2012), Constable et al. (2017) and Morales-Pablos et al. (2020) showed that there is no statistically significant relationship between infection and gender $[7,26,53,58,70,71]$. Generally, the MAP, not attending to a specific gender, infects both males and females and infection is not related to sex determinants such as hormonal, occupational, behavioral and genetic determinants.

The effect of geographical region on MAP infection rate might be due to the difference in animal management such as herd size, health, feeding and stress. In this study, the relationship between geographical location and infection in cattle, sheep and goats was not statistically significant. However, there was a significant relationship between geographical location and infection in cattle by univariate analysis, which might have appeared due to bias and confounding factors such as age. Therefore, this reported spurious association was eliminated by controlling the confounding factors in multivariate regression. In line with the results of the present study, Cetinkaya et al. (1996), Lombard et al. (2006), and Morales-Pablos et al. (2020) indicated that there is no significant relationship between geographical location and infection $[58,66,72]$. However, Singh et al. (2014) proved that there is a significant relationship between the above mentioned variable [73].

\section{Conclusion}

The current study, as a merely serological survey, showed that true prevalence of MAP is considerable in the cattle, sheep and goat populations in Southwest of Iran; although in cattle it is less than goats and sheep. Because the studied animals are kept mostly together, it is not possible to give a definite opinion about the interspecies transmission of MAP in these animals and a molecular study or culture of feces needs to determine this purpose. Moreover, due to the fact that the relationship between strain and host is not exactly clear and between the two major strains of MAP, type $C$ was isolated from a broad range of animals and thus did not have a particular host; also type $S$ mostly infect sheep and goats and therefore transmission from these species to cattle is low. So, it cannot be resulted that which type of MAP, C or S is the main type in this area. To answer this question, more studies especially from molecular standpoint are needed. So, perhaps more than considering the strain of MAP, serious attention should be paid to the level of infection and economical damage caused by this infection. Therefore, control procedures such as vaccination, keeping the newborn away from the infected mother and omitting and limiting the infected animals should be seriously followed by the animal health authorities to prevent the economic losses. In addition, the function of meat and dairy processing units with applying good hygienic practice and pasteurization could be effective to prevent human contamination from MAP in Southwest of Iran.

\section{Methods}




\section{Area of the study}

The current cross-sectional study was carried out in Khuzestan Province located in the Southwest of Iran. The topographic elevations of this tropical province, located between $48^{\circ} \mathrm{E}$ and $49.5^{\circ} \mathrm{E}$ longitudes and $31^{\circ} \mathrm{N}$ and $32^{\circ} \mathrm{N}$ latitudes, with an area of $63213 \mathrm{~km}^{2}$ and 27 cities vary between 0 and $3740 \mathrm{~m}$. The climate of this area varies from arid to humid. The northern parts of the province experience cold weather, whereas the southern parts experience tropical weather [74]. Therefore, to create regional differences in the epidemiological determinants such as environment and management, Khuzestan Province was divided into four different regions from which, one or three cities were randomly selected. In Khuzestan Province, more than 300,000 cattle, 3.5 million sheep and 2.1 million goats whose breeding is mostly traditional and somewhat semi-industrial are kept [75].

\section{Sample Collection}

Blood samples were randomly collected from 530 cattle, 568 sheep and 368 goats. The required information on each sample, including species, age, sex and geographical location was documented. Furthermore, the mean and standard deviation of the age of cattle were $4.12 \pm 2.66$ years, sheep $3.98 \pm$ 1.59 , and goats $3.17 \pm 1.73$ years. Because of the pathogenesis of the MAP, the long incubation period, seroconversion is unlikely in the young animals, so all of the examined animals were more than 6 months. The absolute frequency of samples based on independent variables was summarized in Tables 1, 2, and 3.

\section{Serological Analysis}

The blood samples were transferred to the laboratory and centrifuged at $3000 \mathrm{rpm}$ for ten minutes. Then, serum was slowly removed from the outer layer of the tube by sampler and was transferred to a microtube which was coded. After, microtubes were kept at $-20^{\circ} \mathrm{C}$ until the checking time by a commercial indirect ELISA kit (ID vet, France) for anti-MAP antibodies. All the samples were tested according to the instructions of company. Moreover, optical density (OD) of individual samples and positive (PC) and negative (NC) controls was read by an ELISA reader (Accua reader, Taiwan) at 450 nanometer. Then, based on the S/P percentage, the results were interpreted.

$$
S / P=\frac{O D_{\text {Sample }}-O D_{N C}}{O D_{P C}-O D_{N C}} \times 100
$$

Based on the above formula, the samples with $70 \% \mathrm{~S} / \mathrm{P}$ or more were considered positive; with S/P higher than $60 \%$ and lower than $70 \%$ were doubtful and with $60 \%$ S/P or lower were estimated negative.

\section{Statistical analysis}


Statistical analysis of the data was performed using SPSS (Version 16.0; SPSS Inc., Chicago, USA). Also, the association between species, age, sex, and geographic location was analyzed by the chi-square test and bivariate and multivariate logistic regression (calculation of odds ratio). Moreover, the Mann-Whitney $\mathrm{U}$ and Kruskal-Wallis tests were used to compare the age of infected and non-infected animals in one species and between species, respectively. Cramer's V coefficient value was calculated to determine the correlation between species and infection. Besides, the percentage of true prevalence (TP, the proportion of truly infected animals with MAP) was calculated based on apparent prevalence percentage (AP, the proportion of positive animals in ELISA) and sensitivity (Se) and specificity (Sp) of ELISA kit using the formula TP $=(A P+S p-1) /(S e+S p-1)$. Also, estimation of confidence intervals for proportion was calculated by the Agresi-Coull method [36]. Also, $a=0.05$ was considered as the statistical basis.

\section{Declarations}

Acknowledgments This study was financially supported by the Faculty of Veterinary Medicine, Shahid Chamran University of Ahvaz, Ahvaz, Iran.

\section{Authors' contributions}

MPB and MRHH designed the work and wrote the manuscript. MG, HES, SB and SR performed experiments and acquired data. MPB analyzed and interpreted the data. All authors read, and approved the final manuscript.

\section{Funding}

We are grateful to the Research Council of Shahid Chamran University of Ahvaz for financial support (Grant Number: SCU.vF98.637).

\section{Ethics approval and consent to participate}

The research protocol was reviewed and approved by the Faculty of Veterinary Medicine, Shahid Chamran University of Ahvaz and Khuzestan Veterinary Network. Before beginning work on the present study, we contacted the farm owners and written informed consent was obtained from the owners for the participation of their animals in this study. During collecting blood specimens, these animals were not disturbed.

\section{Consent for publication}

Not applicable.

\section{Competing interests}

The authors declare that they have no competing interests.

\section{Author details}


${ }^{1}$ Department of Food Hygiene, Faculty of Veterinary Medicine, Shahid Chamran University of Ahvaz, Ahvaz, Iran. ${ }^{2}$ Department of Clinical Sciences, Faculty of Veterinary Medicine, Shahid Chamran University of Ahvaz, Ahvaz, Iran. ${ }^{3}$ Department of Pathobiology, Faculty of Veterinary Medicine, Shahid Chamran University of Ahvaz, Ahvaz, Iran.

\section{References}

1. Whittington RJ, Sergeant ES. Progress towards understanding the spread, detection and control of Mycobacterium avium subsp paratuberculosis in animal populations. Aust Vet J. 2001;79:267-78.

2. Manning EJB. Paratuberculosis in captive and free-ranging wildlife. Vet Clin North Am: Food Anim Pract. 2011;27:621-30.

3. Sweeney RW, Collins MT, Koets AP, Mcguirk SM, Roussel AJ. Paratuberculosis (Johne's disease) in cattle and other susceptible species. J Vet Intern Med. 2012;26:1239-50.

4. OIE. https://www.oie.int/en/animal-health-in-the-world/oie-listed-diseases-2020.

5. Tiwari A, VanLeeuwen JA, McKenna SL, Keefe GP, Barkema HW. Johne's disease in Canada Part I: clinical symptoms, pathophysiology, diagnosis, and prevalence in dairy herds. Can Vet J. 2006;47:874 882.

6. Attili AR, Ngu NV, Preziuso S, Pacifici L, Domesi A, Cuteri V. Ovine paratuberculosis: a seroprevalence study in dairy flocks reared in the Marche region, Italy. Veterinary Medicine International Journal. 2011;54:1-10.

7. Constable PD, Hinchcliff KW, Done SH, Granberg W. Veterinary Medicine 11th edition, W.B. Saunders Copmpany, London, UK. 2017; pp, 552-572.

8. Parka TK, Allen AJ, Bannantine JP, Seo KS, Hamilton MJ, Abdellrazaq GS, et al. Evaluation of two mutants of Mycobacterium avium subsp. paratuberculosis candidates for a live attenuated vaccine for Johne's disease. Vaccine. 2011;29:4709-19.

9. Waddell LA, Rajic A, Stark KD, McEwen SA. The potential public health impact of Mycobacterium avium ssp. paratuberculosis: global opinion survey of topic specialists. Zoonoses Public Health. 2016;63:212-22.

10. Waddell LA, Rajic A, Stark KDC, McEwen SA. The zoonotic potential of Mycobacterium avium ssp. paratuberculosis: a systematic review and meta-analyses of the evidence. Epidemiol Infect. 2015;143:3135-57.

11. van Roermund HJW, Bakker D, Willemsen PTJ, de Jong MCM. Horizontal transmission of Mycobacterium avium subsp. paratuberculosis in cattle in an experimental setting: calves can transmit the infection to other calves. Vet Microbiol. 2007;122:270-9.

12. Whittington RJ, Windsor PA. In utero infection of cattle with Mycobacterium avium subsp. paratuberculosis: a critical review and meta-analysis. Vet J. 2009;179:60-9.

13. Windsor PA, Whittington RJ. Evidence for age susceptibility of cattle to Johne's disease. Vet J. 2010;184:37-44. 
14. Mortier RAR, Barkema HW, De Buck J. Susceptibility to and diagnosis of Mycobacterium avium subsp. paratuberculosis infection in dairy calves: a review. Prev Vet Med. 2015; 121:189-198.

15. OIE

OIE Terrestrial Manual https://

OIE. Paratuberculosis (Johne's Disease). OIE Terrestrial Manual https://, 2018; pp:544 559.

16. Stevenson K, Alvarez J, Bakker D, Biet F, de Juan L, Denham S, et al. Occurrence of Mycobacterium avium subspecies paratuberculosis across host species and European countries with evidence for transmission between wildlife and domestic ruminants. BMC Microbiol. 2009;7:9, 212. doi:10.1186/1471-2180-9-212.

17. Bryant JM, Thibault VC, Smith DGE, McLuckie J, Heron I, Sevilla IK, et al. Phylogenomic exploration of the relationships between strains of Mycobacterium avium subspecies paratuberculosis. BMC Genomics. 2016;17:79. https://doi.org/10.1186/s12864-015-2234-5.

18. Nielsen SS, Toft N. Ante mortem diagnosis of paratuberculosis: a review of accuracies of ELISA, interferon-g assay and fecal culture techniques. Vet Microbiol. 2008;129:217-35.

19. Magombedze G, Ngonghala CN, Lanzas C. Evalution of the "Iceberg Phenomenon” in Johne's disease through mathematical modelling. PLoS One. 2013;8:e76636. doi:10.1371/journal.pone.0076636.

20. Ricchi M, Bertasio C, Boniotti MB, Vicari N, Russo S, Tilola M, et al. Comparison among the quantification of bacterial pathogens by qPCR, dPCR, and cultural methods. Front Microbiol. 2017;8:1174. doi:10.3389/fmicb.2017.01174.

21. Anzabi Y, Tabatabayi AH, Asgharzadeh M. A survey on the infection status of Mycobacterium avium paratuberculosis in dairy cattle using PCR of Tabriz. Journal of Iran veterinary science. 2005;4:12531.

22. Haji Hajikolaei MR, Ghorbanpoor M, Amirsolaimani M. The prevalence of Mycobacterium paratuberculosis infection in ileocecal valve of cattle slaughtered in Ahvaz abattoir, southern Iran. Iran J Vet Res. 2006;7:77-80.

23. Anzabi Y, Farashi Bonab S, Moggaddam GA. Efficiency of direct microbial diagnosis, IS900 PCR and microbial culture for detection of Mycobacterium avium subsp. paratuberculosis in the feces of apparently healthy cattle. Veterinary Journal of Islamic Azad University Tabriz Branch. 2009;2:30917.

24. Khakpoor M, Fardin M, Ahmadi H, Nehzati A. The infection status of Mycobacterium avium paratuberculosis in traditional dairy cattle farms in Moghan region. Journal of Food Hygiene. 2012;4:45-52.

25. Ghaemmaghami S, khosravi M, Ahmadi M, Deniko A, Haghdin M, Koochakzadeh A. Study of the prevalence rate of John's disease in Markazi province and evaluation of absorbed ELISA for adoption as a diagnostic method. Iranian Veterinary Journal. 2012;8:54-9.

26. Karimi H, Namjoo AR, Momtaz H, Namdari MR. Identification of Mycobacterium avium subsp. paratuberculosis in samples tissue ileum of cattle slaughtered in Shahrekord with Ziehl Neelsen staining and nested PCR method. Journal of Comparative Pathobiology. 2012;8:697-704. 
27. Nassiri MR, Jahandar MH, Soltani M, Mahdavi M, Doosti M. Identification and strain determination of M. paratuberculosis (MAP) by PCR and REA methods based on IS 900 and IS1311 insertion segments. Agriculture Biotechnology Journal. 2012;4:83-96.

28. Heidarnejhad O, Safi S, Mosavari N, Keshavarz R. Sero-prevalence of subclinical paratuberculosis (Johne's disease) in dairy farms of Tehran-Iran using absorbed ELISA assay. Journal of comparative pathobiology. 2017;14:2239-46.

29. Zarei M, Ghorbanpour M, Tajbakhsh S, Mosavari N. Comparison of ELISA method, PCR and ZiehlNeelsen staining of the rectal mucosa for detection of Mycobacterium avium subsp. paratuberculosis infection in cattle. Iranian Veterinary Journal. 2017;13:29-37.

30. Zarei M, Ghorbanpour M, Tajbakhsh S, Mosavari N. Comparison of rapid diagnostic tests to detect Mycobacterium avium subsp. paratuberculosis disseminated infection in bovine liver. Trop Anim Health Prod. 2017;49:1195-200.

31. Haji Hajikoulaei MR, Ghorbanpour M. Fard Bijar kenari A. A study on the prevalence of Mycobacterium avium paratuberclusis in sheep and goat slaughtered at Ahwaz abattoir. Scientific Research Iranian Veterinary Journal. 2002;5:15-22.

32. Nemati M. Detection of Mycobacterium avium subsp. paratuberculosis in the mesenteric lymph nodes of goats by PCR and culture. Journal of Livestock Science Technologies. 2015;3:56-60.

33. Collins MT, Wells SJ, Petrini KR, Collins JE, Schultz RD, Whitlock RH. Evaluation of five antibody detection tests for diagnosis of bovine paratuberculosis. Clin Diagn Lab Immunol. 2005;12:685-92.

34. 10.1016/j.vetmic.2018.08.023

Begg DJ, de Silva K, Di Fiore L, Taylor DL, Bower K, Zhong L, et al Experimental infection model for Johne's disease using a lyophilised, pure culture, seed stock of Mycobacterium avium subsp. paratuberculosis [Veterinary Microbiology 141 (2010) 301-311]. Vet Microbiol. 2018; 141:301-311. DOI: 10.1016/j.vetmic.2018.08.023, PMID: 30193755.

35. Steuer P, Collado B, Avilez C, Tejeda C, Soto JP, Salgado M. Is the transmission of Mycobacterium avium subspecies paratuberculosis (MAP) infection through milk intended to feed calves an overlooked item in paratuberculosis control programs? Trop Anim Health Prod. 2019;52:82-94.

36. Thrusfield M, Christley R, Brown H, Diggle PJ, French N, Howe K, et al. Veterinary Epidemiology. 4th ed. John Wiley \& Sons Ltd, 2018; pp: 259, 276, 292.

37. Chiodini RJ, van Kruiningen HJ. The prevalence of paratuberculosis in culled new England cattle. Cornell Vet. 1986;76:91-104.

38. Collins MT, Sockett DC, Goodger WJ, Cornad TA, Thomas CB, Carr DJ. Herd prevalence and geographic distribution of, and risk factors for, bovine paratuberclosis in Wisconsin. J Am Vet Med Assoc. 1994;204:636-41.

39. Pillars RB, Grooms DL, Woltanski JA, Blair E. Prevalence of Michigan dairy herds infected with Mycobacterium avium subsp. paratuberculosis as determined by environmental sampling. Prev Vet Med. 2009;89:191-6. 
40. Botsaris G, Slana L, Liapi M, Dodd C, Economides C, Rees C, et al. Rapid detection methods for viable Mycobacterium avium subsp. paratuberculosis in milk and cheese. Int J Food Microbiol. 2010;141:87-90.

41. Pradhan AK, Mitchell RM, Kramer AJ, Zurakowski MJ, Fyock TL, Whitlock RH, et al. Molecular epidemiology of Mycobacterium avium subsp. paratuberculosis in a longitudinal study of three Dairy Herds. J Clin Microbiol. 2011;49:893-901.

42. Kaur P, Fillia G, Singh SV, Patil PK, Ravi Kumar GV, Sandhu KS. Molecular epidemiology of Mycobacterium avium subsp. paratuberculosis: IS900 PCR identification and IS1311 polymorphism analysis from ruminants in the Punjab region of India. Comp Immunol Microbiol Infect Dis. 2011;34:163-9.

43. Vilar AL, Santos CS, Pimenta CL, Freitas TD, Brasil AW, Clementino IJ, et al. Herd-level prevalence and associated risk factors for Mycobacterium avium subsp. Paratuberculosis in cattle in the state of Paraiba, Northeastern Brazil. Prev Vet Med. 2015;121:49-55.

44. Lombard JE, Gardnerb IA, Jafarzadehc SR, Fosslera CP, Harrisd B, Capsel RT, et al. Herd-level prevalence of Mycobacterium avium subsp. paratuberculosis infection in United States dairy herds in 2007. Prev Vet Med. 2013;108:234-8.

45. Verdugo C, Valdes MF, Salgado M. Within-herd prevalence and clinical incidence distributions of Mycobacterium avium subsp. paratuberculosis infection on dairy herds in Chile. Prev Vet Med. 2018;154:113-8.

46. Gurung RB, Begg DJ, Whittington RJ. A national serosurvey to determine the prevalence of paratuberculosis in cattle in Bhutan following detection of clinical cases. Vet Med Sci. 2018;4:28895.

47. Lee KW, Jung BY, Moon OK, Yang DK, Lee SH, Kim JY, et al. Seroprevalence of Mycobacterium subsp. avium paratuberculosis in Korean Black Goats (Capra hircusaegagrus). J Vet Med Sci. 2006;68:1379-81.

48. Dimarelli-Malli Z, Stevenson K, Sarris K, Sossidou K. Study of microbiological and molecular typing aspects of paratuberculosis in sheep and goats in Northern Greece. Transbound Emerg Dis. 2009;56:285-90.

49. Villari S, Castiglione F, Monteverde V. Seroprevalence of Mycobacterium avium subsp. paratuberculosis (MAP) in ovine and caprine farms in Trapani, Sicily. In Proceedings of the 17th International Congress of Mediterranean Federation of Health and Production of Ruminants, Perugia, Italy, 2009; pp: 117-118.

50. Liapi M, Leontides L, Kostoulas P, Botsaris G, lacovou Y, Rees C, et al. Bayesian estimation of the true prevalence of Mycobacterium avium subsp. paratuberculosis infection in Cyproit dairy sheep and goat flocks. Small Rumin Res. 2011;95:174-8.

51. Pithua P, Kollias NS. Estimated prevalence of Caprine paratuberculosis in boer goat herds in Missouri, USA. Vet Med Int. 2012; Article ID 674085, 5pages, doi: 10.1155/2012/674085. 
52. Martinez Herrera DI, Villagomez-Cortes JA, Mendez AM, Flores-Castro R. Seroepidemiology of goat paratuberculosis in five municipalities of central Veracruz, Mexico. Trop Subtrop Agroecosyst. 2012;15:82-8.

53. Stau A, Seelig B, Walter D, Schroeder C, Ganter M. Seroprevalence of Mycobacterium avium subsp. paratuberculosis in small ruminants in Germany. Small Rumin Res. 2012;105:361-5.

54. Dixit M, Filia G, Singh SV, Gupta MP. Prevalence of paratuberculosis in small ruminants in Punjab. Indian Vet J. 2013;90:25-6.

55. Kumthekar S, Manning EJB, Ghosh P, Tiwari K, Sharma RN, Hariharan H. Mycobacterium avium sub species paratuberculosis confirmed following serological surveillance of small ruminants in Grenada, West Indies. J Vet Diagn Invest. 2013;25:527-30.

56. Mpenda F, Buza J. Seroprevalence of paratuberculosis in goats and sheep in Arusha, Northern Tanzania. Int J Sci Res (IJSR). 2014;11:541-5.

57. Sergeant ESG, Baldock FC. The estimated prevalence of Johne's disease infected sheep flocks in Australia. Aust Vet J. 2002;80:762-8.

58. Morales-Pablos MI, Mejía-Sánchez P, Díaz-Aparicio E, Palomares-Resendiz EG, Gutiérrez-Hernández $\mathrm{JL}$, Reyna-Granados JR, et al. Risk factors associated with the seroprevalence of paratuberculosis in sheep flocks in the hot-arid region of Sonora, México. Trop Anim Health Prod. 2020;52:1357-63.

59. Hope AF, Kluver PF, Jones SL, Condron RJ. Sensitivity and specificity of two serological tests for the detection of ovine paratuberculosis. Aust Vet J. 2000;78:850-6.

60. Gurung RB, Begg DJ, Purdie AC, Eamens GJ, Whittington RJ. Development of 316v antibody enzymelinked immunosorbent assay for detection of paratuberculosis in sheep. Rev Sci Tech. 2015;34:86979.

61. Sweeney RW, Whitlock RH, Buckley CL, Spencer PA. Evaluation of a commercial enzyme-linked immunosorbent assay for the diagnosis of paratuberculosis in dairy cattle. J Vet Diagn Invest. 1995;7:488-93.

62. Juste RA, Garrido JM, Geijo M, Elguezabal N, Aduriz G, Atxaerandio R, et al. Comparison of blood polymerase chain reaction and enzyme-linked immunosorbent assay for detection of Mycobacterium avium subsp. paratuberculosis infection in cattle and sheep. J Vet Diagn Invest. 2005;17:354-9.

63. Juste RA, Garcia Marin JF, Peris B, Saez de Ocariz CS, Badiola JJ. Experimental infection of vaccinated and non-vaccinated lambs with Myco-bacterium paratuberculosis. J Comp Pathol. 1994;110:185-94.

64. van der Giessen J, van Dijk L, Bleumink-Pluym N, Eger T, Haagsma J, van der Zeijst B. The spatial distribution of Mycobacterium paratuberculosis in infected cattle. In: Chiodini R.J, Collins MT, Bassey EOE, editors, Proceedings of the Fourth International Colloquium on Paratuberculosis, Cambridge, UK, 1995; pp: 61-66.

65. Marquetoux N, Mitchell R, Ridler A, Heuer C, Wilson P. A synthesis of the patho-physiology of Mycobacterium avium subspecies paratuberculosis infection in sheep to inform mathematical modelling of ovine paratuberculosis. Vet Res. 2018;49:27. https://doi.org/10.1186/s13567-018-0522. 
66. Cetinkaya B, Egan K, Harbour DA, Morgan KL. An abattoir-based study of the prevalence of subclinical johne's disease in adult cattle in south west England. Epidemiol Infect. 1996;116:373-9.

67. Woodbine KA, Schukken YH, Green LE, Ramirez-Villaescusa A, Mason S, Moore SJ, et al. Seroprevalence and epidemiological characteristics of Mycobacterium avium subsp. paratuberculosis on 114 cattle farmsin south west England. Prev Vet Med. 2009;89:102-9.

68. Weber MF, Kogut J, de Bree J, van Schaik G, Nielen M. Age at which dairy cattle become Mycobacterium avium subsp. paratuberculosis fecal culture positive. Prev Vet Med. 2010;97:29-36.

69. Fecteau ME, Whitlock RH, Buergelt CD, Sweeney RW. Exposure of young dairy cattle to Mycobacterium avium subsp. paratuberculosis (MAP) through intensive grazing of contaminated pastures in a herd positive for Johne's disease. Can Vet J. 2010;51:198-200.

70. Kimberling CB. Sheep Diseases. 3th ed. London: Febiger; 1988. pp. 233-8.

71. Anderson NV, Robert GH, Alfred MM, Robert HWH. Veterinary Gastroenterology. 2nd ed. London: Lea and Febiger; 1992. pp. 783-9, 790-791.

72. Lombard JE, Wagner BA, Smith RL, McCluskey BJ, Harris BN, Payeur JB, et al. Evaluation of environmental sampling and culture to determine Mycobacterium avium subsp. paratuberculosis distribution and herd infection status on US dairy operations. J Dairy Sci. 2006;89:4163-71.

73. Singh SV, Singh PK, Singh AV, Sohal JS, Kumar N, Chaubey KK, et al. 'Bio-Load' and Bio-Type Profiles of Mycobacterium avium subsp. paratuberculosis infection in the domestic livestock population endemic for Johne's disease: A survey of 28 years (1985-2013) in India. Transbound Emerg Dis. 2014;61:43-55.

74. Zarasvandi A, Carranza EJM, Moore F, Rastmanesh F. Spatio-temporal occurrences and mineralogical-geochemical characteristics of airborne dusts in Khuzestan Province (southwestern Iran). J Geochem Explor. 2011;111:138-51.

75. Statistical center of Iran. https://www.amar.org.ir/Portals/0/News/1396/a-dams96. pdf (2017).

\section{Tables}

Table 1. Prevalence of Mycobacterium avium subsp. paratuberculosis infection in cattle in Southwest of Iran based on age, sex and geographical location determinants 


\begin{tabular}{|c|c|c|c|c|c|c|}
\hline Category & Groups & $\begin{array}{l}\text { Apparent prevalence } \\
\text { (Positive N./Total N.) }\end{array}$ & $\begin{array}{l}\text { True } \\
\text { prevalence }\end{array}$ & $\begin{array}{l}\text { Odds } \\
\text { Ratio }\end{array}$ & $\begin{array}{l}95 \% \mathrm{Cl} \\
\text { for OR }\end{array}$ & $\begin{array}{l}\mathrm{P} \text { - } \\
\text { value }\end{array}$ \\
\hline \multirow[t]{3}{*}{ Age } & $\leq 2^{\mathrm{a}}$ & $3.26 \%(3 / 92)$ & $5.14 \%$ & & & \\
\hline & $3-4^{a}$ & $4.31 \%(9 / 209)$ & $7.52 \%$ & & & \\
\hline & $\geq 5^{a}$ & $4.8 \%(11 / 229)$ & $8.64 \%$ & 1.02 & $\begin{array}{l}0.88- \\
1.19\end{array}$ & 0.8 \\
\hline \multirow[t]{2}{*}{ Sex } & Male ${ }^{a}$ & $2.38 \%(1 / 42)$ & $3.14 \%$ & 1 & - & - \\
\hline & Female $^{a}$ & $4.51 \%(22 / 488)$ & $7.98 \%$ & 1.94 & $\begin{array}{l}0.25- \\
14.73\end{array}$ & 0.52 \\
\hline \multirow{9}{*}{$\begin{array}{l}\text { Geographical } \\
\text { location }\end{array}$} & Ramhormoz ${ }^{\mathrm{b}}$ & $0 \%(0 / 59)$ & $0 \%$ & - & - & - \\
\hline & Susangerd ${ }^{b}$ & $0 \%(0 / 60)$ & $0 \%$ & - & - & - \\
\hline & Dezfulab & $1.92 \%(1 / 52)$ & $2.09 \%$ & 1 & - & - \\
\hline & Baq-Malek $^{\text {ab }}$ & $2.7 \%(2 / 74)$ & $3.86 \%$ & 1.42 & $\begin{array}{l}0.13- \\
16.05\end{array}$ & 0.78 \\
\hline & Shadegan ${ }^{\mathrm{ab}}$ & $3.45 \%(2 / 58)$ & $5.57 \%$ & 1.82 & $\begin{array}{l}0.16- \\
20.69\end{array}$ & 0.63 \\
\hline & Ahvaz ${ }^{\mathrm{ab}}$ & $4.44 \%(2 / 45)$ & $7.82 \%$ & 2.37 & $\begin{array}{l}0.21- \\
27.07\end{array}$ & 0.49 \\
\hline & Shushtar ${ }^{\mathrm{ab}}$ & $6.98 \%(3 / 43)$ & $13.59 \%$ & 3.83 & $\begin{array}{l}0.38- \\
38.18\end{array}$ & 0.25 \\
\hline & Behbahan $^{\mathrm{ab}}$ & $7.41 \%(6 / 81)$ & $14.57 \%$ & 4.08 & $\begin{array}{l}0.48- \\
34.91\end{array}$ & 0.2 \\
\hline & Hendijan $^{a}$ & $12.07 \%(7 / 58)$ & $25.16 \%$ & 7.00 & $\begin{array}{l}0.83- \\
58.96\end{array}$ & 0.07 \\
\hline
\end{tabular}

The different lowercase letters represent a significant difference.

Table 2. Prevalence of Mycobacterium avium subsp. paratuberculosis infection in sheep in Southwest of Iran based on age, sex and geographical location determinants 


\begin{tabular}{|c|c|c|c|c|c|c|}
\hline Category & Groups & $\begin{array}{l}\text { Apparent prevalence } \\
\text { (Positive N./Total N.) }\end{array}$ & $\begin{array}{l}\text { True } \\
\text { prevalence }\end{array}$ & $\begin{array}{l}\text { Odds } \\
\text { Ratio }\end{array}$ & $\begin{array}{l}95 \% \mathrm{Cl} \\
\text { for } \mathrm{OR}\end{array}$ & $\begin{array}{l}\mathrm{P}- \\
\text { value }\end{array}$ \\
\hline \multirow[t]{3}{*}{ Age } & $\leq 2^{\mathrm{a}}$ & $6.06 \%(6 / 99)$ & $11.5 \%$ & & & \\
\hline & $3-4^{a}$ & $7.65 \%(29 / 379)$ & $15.11 \%$ & & & \\
\hline & $\geq 5^{a}$ & $4.44 \%(4 / 90)$ & $7.82 \%$ & 0.96 & $\begin{array}{l}0.78- \\
1.18\end{array}$ & 0.52 \\
\hline \multirow[t]{2}{*}{ Sex } & Male ${ }^{a}$ & $2.22 \%(1 / 45)$ & $2.77 \%$ & 1 & - & - \\
\hline & Female $^{a}$ & $7.27 \%(38 / 523)$ & $14.25 \%$ & 3.45 & $\begin{array}{l}0.46- \\
25.71\end{array}$ & 0.33 \\
\hline \multirow{7}{*}{$\begin{array}{l}\text { Geographical } \\
\text { location }\end{array}$} & Baq-Malek $^{\mathrm{a}}$ & $3.7 \%(3 / 81)$ & $6.14 \%$ & 1 & - & - \\
\hline & Ahvaz ${ }^{a}$ & $4.42 \%(5 / 113)$ & $7.77 \%$ & 1.2 & $\begin{array}{l}0.28- \\
5.19\end{array}$ & 1 \\
\hline & Susangerd ${ }^{\mathrm{a}}$ & $5 \%(3 / 60)$ & $9.09 \%$ & 1.37 & $\begin{array}{l}0.27- \\
7.03\end{array}$ & 1 \\
\hline & Hendijan $^{a}$ & $6.52 \%(6 / 92)$ & $12.55 \%$ & 1.81 & $\begin{array}{l}0.44- \\
7.5\end{array}$ & 0.62 \\
\hline & Dezfula $^{a}$ & $7.69 \%(5 / 65)$ & $15.2 \%$ & 2.17 & $\begin{array}{l}0.5- \\
9.43\end{array}$ & 0.49 \\
\hline & $\begin{array}{l}\text { Masjed } \\
\text { Soleyman }^{a}\end{array}$ & $10.71 \%(9 / 84)$ & $22.07 \%$ & 3.12 & $\begin{array}{l}0.81- \\
11.97\end{array}$ & 0.15 \\
\hline & Gotvand $^{a}$ & $10.96 \%(8 / 73)$ & $22.64 \%$ & 3.2 & $\begin{array}{l}0.82- \\
12.56\end{array}$ & 0.15 \\
\hline
\end{tabular}

The different lowercase letters represent a significant difference.

Table 3. Prevalence of Mycobacterium avium subsp. paratuberculosis infection in goats in Southwest of Iran based on age, sex and geographical location determinants 


\begin{tabular}{|c|c|c|c|c|c|c|}
\hline Category & Groups & $\begin{array}{l}\text { Apparent prevalence } \\
\text { (Positive N./Total N.) }\end{array}$ & $\begin{array}{l}\text { True } \\
\text { prevalence }\end{array}$ & $\begin{array}{l}\text { Odds } \\
\text { Ratio }\end{array}$ & $\begin{array}{l}95 \% \mathrm{Cl} \\
\text { for OR }\end{array}$ & $\begin{array}{l}\mathrm{P}- \\
\text { value }\end{array}$ \\
\hline \multirow[t]{3}{*}{ Age } & $\leq 2^{\mathrm{a}}$ & $6.3 \%(8 / 127)$ & $12.05 \%$ & & & \\
\hline & $3-4^{a}$ & $7.43 \%(13 / 175)$ & $14.61 \%$ & & & \\
\hline & $\geq 5^{a}$ & $7.58 \%(5 / 66)$ & $14.95 \%$ & 1.08 & $\begin{array}{l}0.86- \\
1.35\end{array}$ & 0.92 \\
\hline \multirow[t]{2}{*}{ Sex } & Male $^{a}$ & $6.15 \%(4 / 65)$ & $11.7 \%$ & 1 & - & - \\
\hline & Female $^{a}$ & $7.26 \%(22 / 303)$ & $14.23 \%$ & 1.19 & $\begin{array}{l}0.4- \\
3.59\end{array}$ & 0.96 \\
\hline \multirow{6}{*}{$\begin{array}{l}\text { Geographical } \\
\text { location }\end{array}$} & Hendijan $^{a}$ & $2.67 \%(2 / 75)$ & $3.8 \%$ & 1 & - & - \\
\hline & $I_{z e h}{ }^{a}$ & $4.92 \%(3 / 61)$ & $8.91 \%$ & 1.89 & $\begin{array}{l}0.31- \\
11.68\end{array}$ & 0.81 \\
\hline & Dezful $^{a}$ & $5 \%(3 / 60)$ & $9.09 \%$ & 1.92 & $\begin{array}{l}0.31- \\
11.89\end{array}$ & 0.8 \\
\hline & $A^{\prime h v a z}{ }^{a}$ & $8.06 \%(5 / 62)$ & $16.05 \%$ & 3.2 & $\begin{array}{l}0.6- \\
17.11\end{array}$ & 0.3 \\
\hline & Susangerd ${ }^{a}$ & $10 \%(5 / 50)$ & $20.45 \%$ & 4.06 & $\begin{array}{l}0.76- \\
21.79\end{array}$ & 0.18 \\
\hline & Shushtar ${ }^{a}$ & $13.33 \%(8 / 60)$ & $28.02 \%$ & 5.62 & $\begin{array}{l}1.15- \\
27.53\end{array}$ & 0.04 \\
\hline
\end{tabular}

The different lowercase letters represent a significant difference. 